\title{
DEVELOPMENT OF LEARNING MEDIA FOR THE GAME OF SNAKES AND LADDERS TO INCREASE STUDENTS LEARNING INTEREST IN THE PPKN SUBJECT FOR CLASS III SD NEGERI 024776 BINJAI
}

\author{
Nina Junisa Sianipar ${ }^{1}$ \\ State University of Medan, Indonesia \\ E-mail : nina.junisa.sianipar@gmail.com \\ Ramli Nur ${ }^{2}$ \\ State University of Medan, Indonesia \\ E-mail : ramli.nur@gmail.com \\ Dede Ruslan ${ }^{3}$ \\ State University of Medan, Indonesia \\ E-mail :dede.ruslan@gmail.com
}

\begin{abstract}
This study aims to produce an innovative learning media product by developing learning media for snakes and ladders to be applied in the learning process. In this research the product is first validated by media experts and material experts. As well as assessment of responses from teachers and students. Products in the form of learning media for the game of snakes and ladders will be tested first in small groups and then in limited groups. The objectives of this study were (1) Obtaining the feasibility, practicality, and effectiveness of the snake and ladder learning media in PPKn subjects in class III SD Negeri 024776 Binjai from material experts and media experts, (2) Knowing the differences in interests and learning outcomes of students who use and not. using snake and ladder learning media in PPKn subjects in class III SD Negeri 024776 Binjai. Development This research was developed with the ADDIE development model, starting from the analysis, design stage, development stage, implementation stage, and evaluation stage. Based on the results of the analysis of experts consisting of material experts with an average value of 82.26, it means that it is very valid and with media experts with
\end{abstract}


an average value of 89 it means very valid. The percentage value of classical completeness obtained by students in the pretest and posttest of the experimental group experienced a high increase, namely $40 \%$ to 95\%, with an average pretest score of 59.00 and an average posttest score of 81.25 . So that it has met the criteria for classical completeness and the learning media products have met the indicators of effectiveness and are suitable for use.

Keywords: Development, Learning Media, Interest and Learning Outcomes

\section{A. Introduction}

Education is very important for someone's life. It is from the scope of education that a person gets a lesson. With education, a person can master all fields, both in terms of science and technology. Improving the quality of education must continue to be improved in line with the times. In this era, technology development is also very fast in all fields. Mastery of technology is also used as a means of education in Indonesia, one of which is by utilizing technology that can be done by educators in learning.

According to Setiawan (2016: 2) "Citizenship Education is a subject which is a series of processes to direct students to become citizens with Indonesian national character, smart, skilled, and responsible so that they can play an active role in society in accordance with the provisions of the Pancasila and the Constitution. 1945.

The learning media used must also be innovative so that they can attract students interest to learn. The teacher has a role to choose or design the appropriate learning media to use. Because in essence learning media is a tool in the learning process. Media is a tool that can be used to stimulate students thoughts, feelings, attention, and abilities or skills so as to encourage the learning process. 
According to Tafonao (2018: 103) in his journal, he states the reasons why there are still many teachers who do not use learning media, namely:

(1). The teacher thinks that using the media needs preparation. (2). Media is sophisticated and expensive. (3). Unusual to use media (stuttering technology). (4). Media is only for entertainment, while learning must be serious. (5). The media is not available in schools, schools do not have the equipment and materials to make learning media. (6). The teacher does not understand the importance of using learning media. (7). The teacher does not have the knowledge and ability about how to make their own learning media. (8). The teacher does not have the skills to use learning media. (9). Teachers do not have the opportunity (time) to make learning media. (10). Teachers are used to relying on the lecture method.

Based on the results of observations made by researchers on January 15, 2019 at SD Negeri 024776 Binjai, it was found that there were still many teachers who in the learning process did not use learning media, even they only used the lecture method and then gave assignments to students. Students also look unenthusiastic, they just sit quietly and then write, there are even students who do not listen to the teacher when explaining the lesson. The researcher also saw that in low classes, especially in grade 3 , the teachers in that class were the same as other teachers who only used the lecture method. as it is known that elementary school children who are at low grade levels have not been able to fully develop their cognitive abilities, so that the role of the teacher is very influential. 


\section{B. Method}

\section{Development style}

Development research is a research method that is used to develop a product and is carried out in certain stages, resulting in a product that has been tested for its validity, practicality, and effectiveness on needs. According to Sugiyono (2011: 407) "Research and development methods are research methods used to produce certain products and test the effectiveness of certain products. In this study, it was carried out to develop a product in the form of learning media for the game of snakes and ladders in PPKn learning in grade III SD.

The development model used in this study is the ADDIE model developed by Dick and Carry in 1996. The ADDIE model consists of five stages, namely Analysis, Design, Development, Implementation, and Evaluation (evaluate).

\section{Finding and Discussion}

\section{Results}

In this research, the trial phase was carried out by material experts, media experts, teachers and students by placing a limited trial with a total of 20 students. The following is a presentation of the trial data

Presentation of Data on the Design Results of Learning Media for Snake and Ladder Learning

The PPKN ladder snake development follows the ADDIE development model which consists of five stages, namely the analysis, design, development, implementation, and evaluation stages. The detailed implementation of the entire development procedure in this study can be seen in the following description: 


\section{Description of the Results of the Analysis Stage}

Based on the results of observations on The teaching media used by the teacher during the learning process indicate that there are weaknesses in the teaching media used in the learning process in the classroom. Based on field observations, the implementation of learning is not in accordance with students learning interests. Students still often experience boredom in class. When making observations, there are still students sleeping in class, besides that learning is also not conducive like talking at the end of the class, this is because the teacher does not use media that encourages students to be active in learning. The preparation of the media is part of the planning of the learning process. Therefore, there will be development of snake and ladder media with the theme "Energy and its changes" based on Local Culture which is expected to be in accordance with the criteria of good media.

\section{Description of the Design Stage Results}

Based on the analysis at the definition stage, the design of the snake and ladder media with the theme of energy and change based on local culture was carried out to increase the interest in learning of third grade students of SD Negeri 024776 Binjai. Media according to the basic competency set by the curriculum. Snake and ladder media designed to encourage students to take an active role in learning. The snake and ladder media is equipped with colorful and attractive pictures for students. The snake and ladder media with the theme of energy and change shows that the activities in the media are presented in the form of communicative sentences and pictures. Thus the designer of this media will be more liked by students and can support the learning process later.

\section{Descriptions of the Development Stage Results}

The results of the define and design stages produce an initial 
design of a teaching medium called draft I. Next is the develop stage or the development stage. The first phase in the development stage is to validate draft I. Expert validation is focused on the format, content, illustrations, and language of the learning tools being developed.

To see the value of the validation results of teaching media clearly, it can be seen in the following diagram:

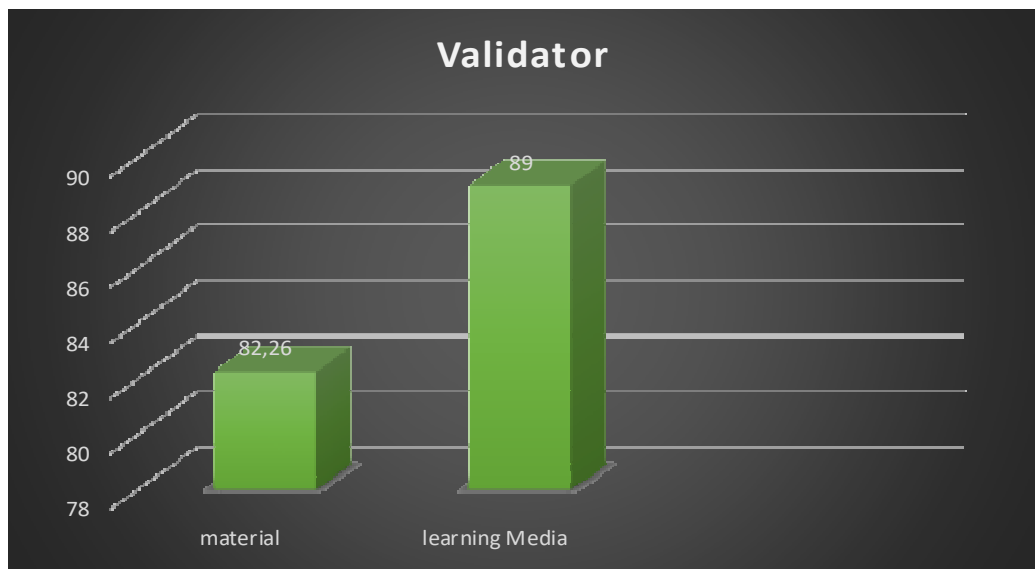

Figure 1. Diagram of Teaching Media Validation Results

Based on the diagram above, it can be seen the results of the validation on the teaching media carried out by the validators. The average given by material experts on teaching media products is 82.26, learning media for teaching media products is 89 . The average acquisition of this assessment is included in the very valid category and can be used with several suggestions and improvements to be revised. Furthermore, the results of the validation from this expert team were referred to the validity criteria set in chapter III, it can be concluded that the teaching media developed met the valid criteria and could be used.

\section{Implementation Stage (Implementation)}

Implementation is the stage that is carried out after developing learning media. Learning media that have been developed and have 
received approval from expert validators can be used in the field according to development objectives. Implementation is the stage where learning media have been developed for use in the field in the learning process. In addition to conducting field trials, the attractiveness of learning media also needs to be known.

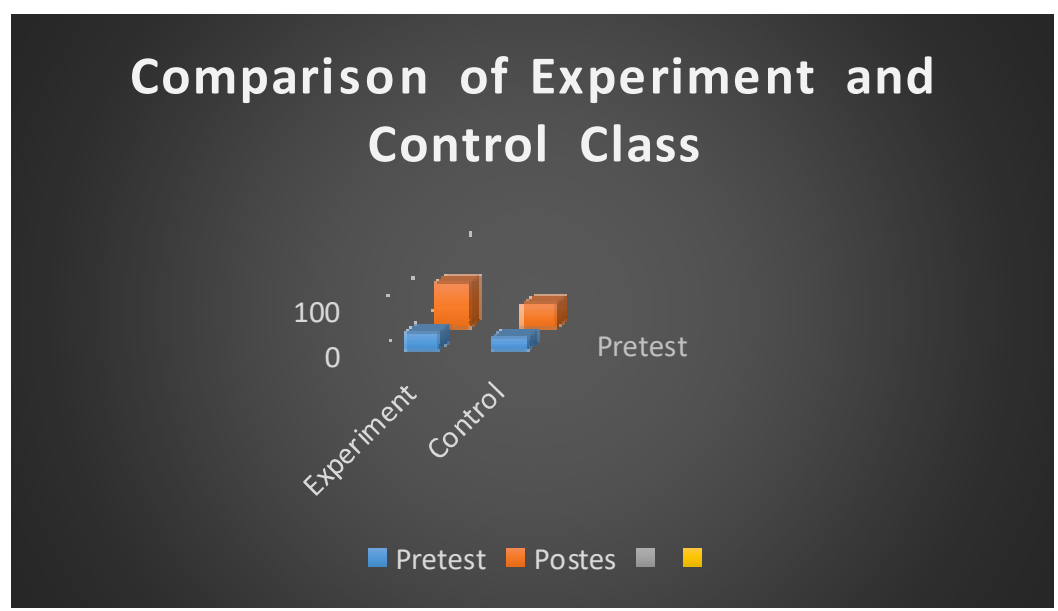

Figure 2. Comparison diagram of pretest and posttest results in the experimental and control class

Based on Figure 2, it can be seen that there is a difference in the percentage value of classical completeness obtained by students in the experimental class and the control class. The percentage value of classical completeness obtained by students in the pretest and posttest of the experimental group was higher, namely $40 \%$ and $95 \%$, where the gain score was 0.54 , while in the pretest and posttest control class the values obtained were $30 \%$ and $50 \%$ with the gain score is 0.23 .

\section{Descriptions of Evaluation (Evaluation)}

Media that has gone through the implementation stage are then evaluated. At this stage an evaluation is carried out to determine the 
effectiveness of media development in increasing student interest in learning. The increase in student interest in learning can be seen from the measurement of interest in learning before and after learning by using a questionnaire with a Likert scale. The questionnaire contains 20 statements. The questionnaire has been through empirical tests. In the evaluation stage, the activities carried out are evaluating matters related to the development of snake and ladder media. Products that have been developed and tested are then revised in accordance with the results of the evaluation of needs, namely to determine the level of success in the development and implementation of the teaching media that has been made.

After the teaching media is assessed by the validator to determine its feasibility, the next step is field testing. By using teaching media in class. And to determine the achievement of the development goals, namely the improvement of learning outcomes, a posttest is carried out, and then it is compared with the results obtained before using the teaching media, namely the pretest.

Pretest carried out by using the old learning media, while the posttest is carried out with learning activities using the developed learning media.

\section{Discussion}

feasibility, practicality, and effectiveness of learning media for snakes and ladders in PPKn subjects in class III SD Negeri 024776 Binjai

Feasibility of Learning Media for Snakes and Ladders

According to Jalinus (2016: 4) states "learning media is anything related to software and hardware that can be used to convey the content of teaching material from learning sources to students (individuals or groups) which can stimulate the thoughts, feelings, attention, and [468] 
interests of learners. in such a way that the learning process (inside / outside the classroom) becomes more effective.

A good teaching media should meet the validity criteria Plomp (207: 127) explains that the characteristics of a product that are said to be valid are if it reflects the soul of knowledge (state-of-art-knowledge). Inni known as content validity. While the product components must be consistent with each other, it can be said to be valid if they meet the content and construct validity criteria. The acquisition of teaching media validity can be seen in the following table:

Table 2. Results of Teaching Media Validation

\begin{tabular}{cccc}
\hline No. & Validator & Score & Average \\
\cline { 1 - 3 } 1 & Theory & 82.26 & 85.63 \\
\cline { 1 - 3 } & Learning Media & 89 & \\
\hline
\end{tabular}

In this study, the learning media for the game of snakes and ladders were assessed for its feasibility by material experts and media experts, as well as teacher response assessments. Based on the comparison of the results of the validation of the game of snakes and ladders, the average score given by material experts on teaching media products is 82.26 with the categoryvery valid and instructional media experts on teaching media products of 89 with a very valid category. With the level of validity of media experts and material experts, it can be said that the Snake and Ladder Game Learning Media is feasible to use.

Practicality of Learning Media for Snakes and Ladders

From the expert validation sheet and student response questionnaires that have been given to all students, this media can be said to be practical. This is in accordance with the statement according to Yamasari (2010: 3) saying that "learning media is said to be practical if it meets several indicators". The first indicator is the validator stating that 
the learning media can be used with little or no revision. This can be seen from the results of the expert validation questionnaire who only received a few suggestions for improvements or revisions to the Snakes and Ladders Learning Media products. While the second indicator is that students give a positive response, which is indicated by the results of the questionnaire given by the test subjects. This is evidenced by the results of trials and questionnaires to third grade elementary school students who gave a positive response,

\section{The Effectiveness of Learning Media for Snakes and Ladders}

The learning media used are effective if the learning objectives that have been set can be achieved compared to certain criteria. A student is said to be complete if the student learning outcomes at a certain competency standard have reached the minimum completeness criteria (KKM) set by the school. In this study, the completeness of learning a class is said if in the class there are $85 \%$ who have reached $K B \geq 65 \%$.

According to Yamasari (2010) learning media is said to be effective if it meets two indicators. The first indicator is the average score of student learning outcomes that is obtained by the subject of the trial is complete, while the second indicator is the positive response of students shown through a given questionnaire.

This can be seen from the test results in the experimental class, where classical completeness increased from the students pretest and posttest by $40 \%$ to $95 \%$. The pretest value based on the classical learning completeness criteria is classified as incomplete, while the post-test score based on the classical learning completeness criteria is classified as complete. Where the average value of the pretest results was 59.00, there were 8 students who completed learning. While the average post- 
test score was 81.25 , students who completed learning were 19 out of 20 students.

Furthermore, based on the results of the student response questionnaire after the use of snake and ladder learning media in the limited field test stage, the results were: (1) $79 \%$ of students said they were happy with the learning components and activities; (2) 83\% of students stated that the learning components and activities were still new; (3) $85 \%$ of the students stated that they were interested in taking part in learning using snake and ladder learning media; (4) 75\% of students stated that the language in the learning media was clear; and (5) 90\% expressed interest in the appearance of learning media. The average percentage of total student positive responses to product trials was $82 \%$. If the results of this analysis are referred to the criteria set out in chapter III, it can be concluded that the student's response to the components and learning activities is positive.

Increased interest and student learning outcomes using snake and ladder learning media in PPKn subjects in class III SD Negeri 024776 Binjai

Based on the measurement of students interest and learning outcomes before and after the implementation of the use of the Snake and Ladder Game Learning Media, the average score of interest in the control class was 56 scores then at the next meeting it was 64 scores. Then in the experimental class, namely 51 and at the second meeting, there was an increase after the application of the snake and ladder learning media to an average score of 87.

In addition to increasing interest in learning through questionnaires, there is also an increase in learning outcomes obtained 
through tests. Where the average value of the pretest results in the control class is 55.00, there are 6 students who have completed learning. While the average post-test score is 65.50, students who complete learning are 10 students out of 20 students. Meanwhile, in the experimental class there was an average pretest result, namely 59.00, students who completed learning were 8 students. While the average post-test score was 81.25 , students who completed learning were 19 out of 20 students who completed the study.

Based on the results of the above research, we can see that teaching media plays an important role in learning to improve student learning outcomes in class. Not only that, the learning process makes students more active and fun, because of the pictures and knowledge about the environment around the house. This will generate interest in learning in class.

This is consistent with the theory of John Dewey. For Dewey, learning is part of the interaction with the environment. Children must be guided towards the use of the environment. Based on the results of the research analysis and theoretical study above, it is true that the teaching media developed is appropriate to be used to increase student interest and learning outcomes.

\section{Conclusion}

The conclusions that can be drawn based on the results of the study of the research results and the discussion in the previous chapter include:

1. The result of this research is a teaching media product for snakes and ladders with the theme Energy and Change. This product is feasible and valid for use in class III SD Negeri 024776 Binjai through [472] 
assessments, revisions and validations from several experts. This conclusion is drawn based on the results of the analysis of experts consisting of material experts with an average value of 82.26 which means very valid and with media experts with an average value of 89 which means very valid.

2. The learning media used are effective for use. This can be seen from the results of the analysis of the effectiveness of instructional media. The effectiveness of learning media is based on product trials with two phases, namely small group evaluation and limited trials. In the small group evaluation phase the percentage was $77 \%$ and in the limited trial phase the percentage was $82 \%$. Comparison between the students 'pre-test and final test that has been done, it is found that there is an increase in students conceptual understanding of Energy and its Change. The percentage value of classical completeness obtained by students in the pretest and posttest of the experimental group experienced a high increase, namely $40 \%$ to $95 \%$, with an average pretest score of 59.00 and an average postest score of 81.25.

\section{Bibliography}

Afandi, Rifki. 2015. Pengembangan Media Pembelajaran Permainan Ular Tangga untuk Meningkatkan Motivasi Belajar Siswa dan Hasil Belajar IPS di Sekolah Dasar. JINoP (Jurnal Inovasi Pembelajaran) vol 1 No. 1 halaman 77-89. ISSN: 2443-1591.

Aris Prasetyo Nugroho, dkk. 2013. Pengembangan Media Pembelajaran Fisika Menggunakan Permainan Ular Tangga Ditinjau Dari Motivasi Belajar Siswa Kelas VIII Materi Gaya. Jurnal Pendidikan Fisika (2013) Vol.1 No.1 halaman ISSN: 2338 - 0691.

Dyah Kartikaningtyas, dkk. 2014. Pengembangan Media Game Ular Tangga Bervisi Sets Tema Energi Pada Pembelajaran IPA Terpadu untuk Mengembangkan Karakter dan Aktivitas Siswa SMP/MTS Unnes Science Education Journal Vol. 3 No. 3. ISSN: 2252:6617. 
Jalinus, Nizwardi \& Ambiyar. 2016. Media \& Sumber Pembelajaran. Jakarta: Kencana.

Kaelan \& Achmad Zubaidi. 2010. Pendidikan Kewarganegaraan. Yogyakarta: Paradigma.

Nugrahani, Rahina. 2007. Media Pembelajaran Berbasis Visual Berbentuk Permainan Ular Tangga untuk Meningkatkan Kualitas Belajar Mengajar di Sekolah Dasar. LEMBARAN ILMU KEPENDIDIKAN JILID 36, NO. 1, JUNI 2007. ISSN: 0216-0847

Setiawan, Deny. 2016. Pendidikan Kewarganegaraan. Medan: Madenatera.

Sugiyono. 2011. Metode Penelitian Pendidikan (Pendekatan, Kuantitatif, Kualitatif, dan R\&D). Bandung: Alfabeta. 